\title{
Spatio-Temporal Dynamic of Land Use and Land Cover in the Classified Forest of Djoli-Kera, South-Eastern, Chad
}

\author{
Lucie Félicité Temgoua1, Behimnan Allaissem¹, Martin Tchamba1, Goy Saradoum², \\ Mbaiakambeye Mbaidje Osée ${ }^{1}$, Marie Caroline Momo Solefack ${ }^{3}$ \\ ${ }^{1}$ Department of Forestry, Faculty of Agronomy and Agricultural Sciences, University of Dschang, Dschang, Cameroon \\ ${ }^{2}$ Department of Biology, University Institute of Agricultural Sciences and Environment, Sarh, Chad \\ ${ }^{3}$ Department of Plant Biology, Faculty of Science, University of Dschang, Dschang, Cameroon \\ Email: felicite.temgoua@univ-dschang.org
}

How to cite this paper: Temgoua, L. F., Allaissem, B., Tchamba, M., Saradoum, G., Osée, M. M., \& Solefack, M. C. M. (2018). Spatio-Temporal Dynamic of Land Use and Land Cover in the Classified Forest of Djoli-Kera, South-Eastern, Chad. Open Journal of Forestry, 8, 283-296.

https://doi.org/10.4236/ojf.2018.83019

Received: May 29, 2018

Accepted: July 10, 2018

Published: July 13, 2018

Copyright $\odot 2018$ by authors and Scientific Research Publishing Inc. This work is licensed under the Creative Commons Attribution International License (CC BY 4.0).

http://creativecommons.org/licenses/by/4.0/

\begin{abstract}
This study was carried out in the classified forest of Djoli-Kera found in the South-Eastern part of Chad. It aimed to analyze the spatial and temporal dynamics of land cover between 1972 and 2013 and to determine the drivers of vegetation degradation. The databases used were made up of 4 Landsat satellite images (1MSS of 1972, 5TM of 1984, 7ETM+ of 1990 and 2010) and a spot 6 image of 2013, supplemented by field studies. Satellite images were processed using ENVI and ArcGIS software. Interview was used to identify the activities carried out by the local population. In 1972, the classified forest consisted of four types of land cover, the most important of which was open forest $(51 \%)$, followed by wooded savannah (26\%), tree savannah (21\%) and sparse vegetation consisting of farms and fallows (2\%). Gradually open forest and tree savannah disappeared. In 2013, the main types of land cover were shrub savannah (40\%), sparse vegetation (28\%), wooded savannah (12\%), bare soil (12\%) and dwellings (8\%). Livestock, agriculture, wood collection and bushfires are perceived by local population as main drivers of forest cover change. Awareness-raising, monitoring and regulation of access to resources must be pursued, but also managers of the classified forest must accompany the local populations in the planting of trees and the setting up of more efficient farming systems to reduce pressure on the forest's resources.
\end{abstract}

\section{Keywords}

Land-Use, Land-Cover, Satellite Images, Degradation, Chad 


\section{Introduction}

Tropical forests are one of the terrestrial ecosystems richest in biodiversity. They offer many forms of habitat for plant, animal and micro-organism species and livelihoods for those living or residing nearby. Tropical forests spread over an area of 1376 million $\mathrm{km}^{2}$, representing $60 \%$ of the world's forests (FAO, 2010) and play a key role in the carbon cycle at both flux and volume levels. They are major challenge for biodiversity conservation, water purification and climate change mitigation (Le Guen, 2010). Despite their importance, tropical forests are facing gradual degradation. High rates of deforestation have been experienced globally particularly in tropical areas. FAO (2016) reported a net annual loss of forest of about 7 million hectares between 2000 and 2010 and increase of agricultural land of 6 million hectare per year in tropical countries. Degradation, deforestation and land uses change in developing countries would contribute for about 20 per cent of the annual global greenhouse gas emissions (Le Guen, 2010). Land uses and Land cover change is one of the most important components of global environmental change (Grau et al., 2003) and an important factor in the degradation and destruction of habitat and the loss of biodiversity (Lucas et al. 2015). In tropical developing countries that are characterized by agriculture-based economies and rapidly increasing human populations, land cover change is very intense (Yeshaneh et al., 2013; Romijn et al., 2015). Remote sensing has proven to be an essential technology for determining land cover at different scales (Loveland \& Dwyer, 2012; Hansen et al., 2013).

The classified forest of Djoli-Kera is one of the ten classified forests in Chad that has for a long time received no protection, either from the state or local communities. Yet it is the Western gateway to the Manda National Park allowing wildlife and floristic exchanges between these two protected areas Saradoum (2012). In this classified forest Ouya (2010) and Saradoum (2010) reported various pressures. These include agricultural pioneer fronts, poaching, collection of firewood and pasture. It was only after 2007, with the launch of "conservation and sustainable use of biodiversity in the medium-Chari" project, that reflections were carried out for the rehabilitation, leading to the participative development of a management plan of the forest. Being a buffer zone of Manda National Park, the classified forest of Djoli-Kera provides several ecological functions, including genetic exchanges between animals of the two protected areas. The density of the vegetation cover made it a temporary habitat and a migration corridor for wildlife (Saradoum, 2012). Given this important role that it plays for both wildlife and climate regulation, this forest deserves special attention. Some studies have been carried out in the classified forest of Djoli-Kera, but have focused on the conservation and sustainable use of biodiversity (Ouya, 2010; Saradoum, 2010). Very little information exists on the land uses and land cover change. Hence the interest of this study, which seeks to assess the spatial and temporal dynamics of land use and land cover in this classified forest. 


\section{Material and Methods}

\subsection{Study Site}

The study was carried out in the classified forest of Djoli-Kera, in South-Eastern part of Chad, specifically in the Mandoul region. This forest is located, between latitudes $9^{\circ} 00^{\prime} 35^{\prime \prime}-9^{\circ} 18^{\prime} 55^{\prime \prime} \mathrm{N}$ and longitudes $17^{\circ} 40^{\prime} 31^{\prime \prime}-18^{\circ} 01^{\prime} 11^{\prime \prime E}$ (Figure 1). Classified in 1955, it covers an area of 93,000 hectares spread over Bedaya and Matekaga subdivisions. The climate is wet tropical type characterized by 02 seasons including one dry season which lasts five months (November to March) and one rainy season (April to October). Temperatures vary from $21^{\circ} \mathrm{C}$ to $35^{\circ} \mathrm{C}$. Annual rainfall varies from $700 \mathrm{~mm}$ to $1400 \mathrm{~mm}$ and the relative humidity from $32 \%$ to $85 \%$ (Boulanodji \& Saradoum, 2013). The soils of the zone are mainly ferralitic, and tropical ferruginous. The vegetation is a mosaic of wooded savannahs and shrub-savannahs dominated by species of combretaceae and leguminoseae. By place, agropastoral activities have led to Sahelian scars of Ziziphus sp. as well as and fallow indicator species (Saradoum, 2010).

\subsection{Data Collection and Analysis}

Satellite images used were Landsat 1MSS, Landsat 5TM, Landsat 7ETM+, respectively for the years 1972, 1986, 1999 and 2010. For 2013, a Spot 6 image was used. These different images were processed using ENVI 4.7 software to extract desired information. The first phase of the processing consisted of colored composition with combination of the different spectral bands of each image in order to form a scene. Extraction of the study zone was made using a geo-rectified vector map (UTM 34 WGS 84). We then carried out a supervised classification (A field mission was made before to identify different land cover

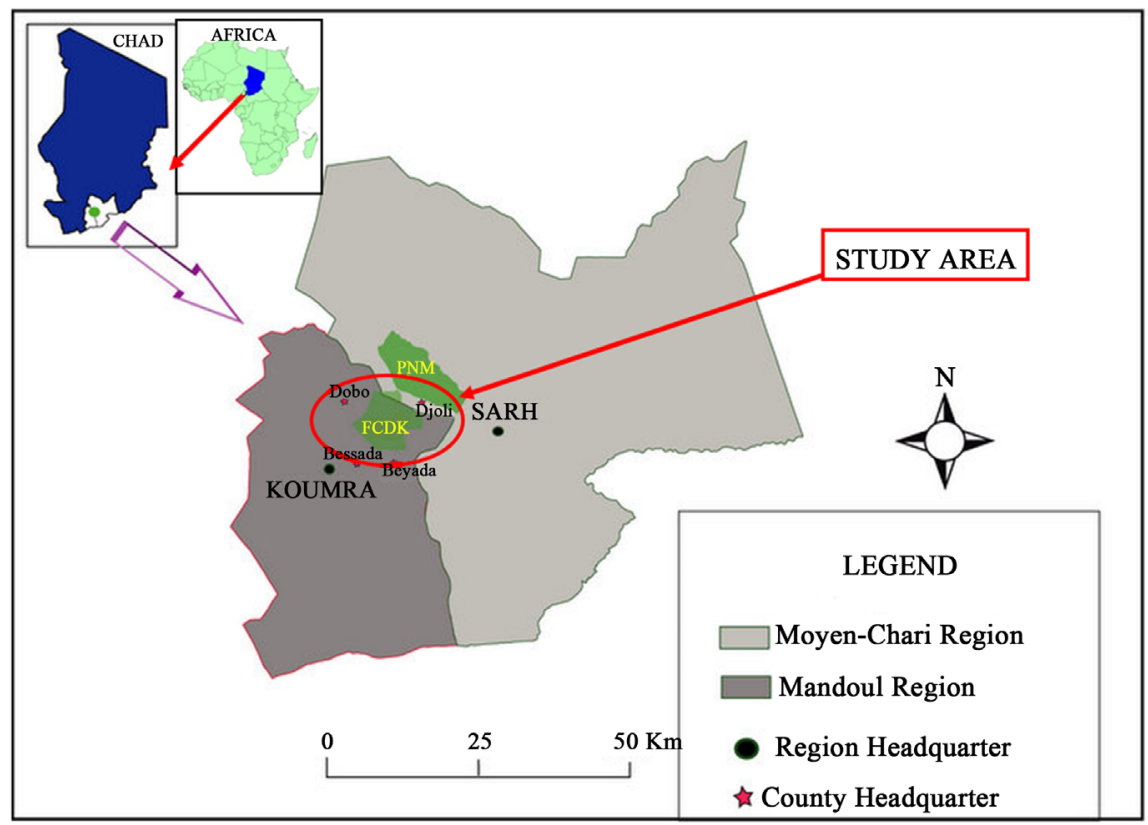

Figure 1. Localization of classified forest of Djoli-Kera. 
types). Finally, vectorization was done and vectors derived from digital processing in ENVI were imported into ArcGIS 10 software for the extraction of the layers to be used, digitization, generation of databases, and production of maps.

Participatory rural appraisal was used, notably, interviews, and participatory observation to identify the agent of degradation and the activities carried out within the classified forest. Surveys mainly involved household heads and 154 persons were interviewed. The surveys were conducted in four cantons (Djoli, Bessada, Bedaya and Dobo). These cantons were selected because of their proximity to the classified forest. Thus all the four cantons in the periphery of the classified forest were chosen. The household heads were randomly selected, based on their availability because the period of the study coincided with the period of cotton and bean harvests. Household interviews were conducted using structured questionnaires designed by the authors of this study and consisting of both open and closed-ended questions. A pretest was necessary to determine how the questionnaire could be improved to minimize response errors, such as a respondent misinterpreting a question.

The Key items of the questionnaire included demographic data, education, size of households and material used for the building of their house, their origins and the time period spent in the cantons, their knowledge of the status of the classified forest, activities carried out in the forest, causes and local perceptions of forest degradation and measures to minimize forest degradation.

The processing of survey data was based on the calculation of relative frequency of citation (RFC) using Excel 2013 software. The RFC is the response rate by type of use. It is expressed by the formula used by Dossou et al. (2012).

$$
\mathrm{RFC}=S / N * 100
$$

With:

$S$ : number of people who provided a response for a given use;

$N$ : total number of people interviewed.

\section{Results}

\subsection{Dynamic of Land Cover}

Analysis of satellite images (Figures 2-6) revealed that in 1972 the Djoli-Kera forest had only four types of land cover. These land cover have evolved in size and physiognomy over the years, either by disappearing completely (open forest) or by losing surface area to give way to other land cover types (wooded savannah). This evolution has shown two other types of land cover: shrub savannahs and bare soils leading to six types of land cover between 1972 and 2013.

Of the four types of land cover of 1972 (Figure 2), the open forest was the most important and represented $51 \%$ of the total surface area. It is followed by the wooded savannah with $26 \%$. These two types of vegetative formation, characteristic of Sudanese climate, were at the origin of the classification of this forest. The tree savannah, which was scattered throughout the forest perimeters, 


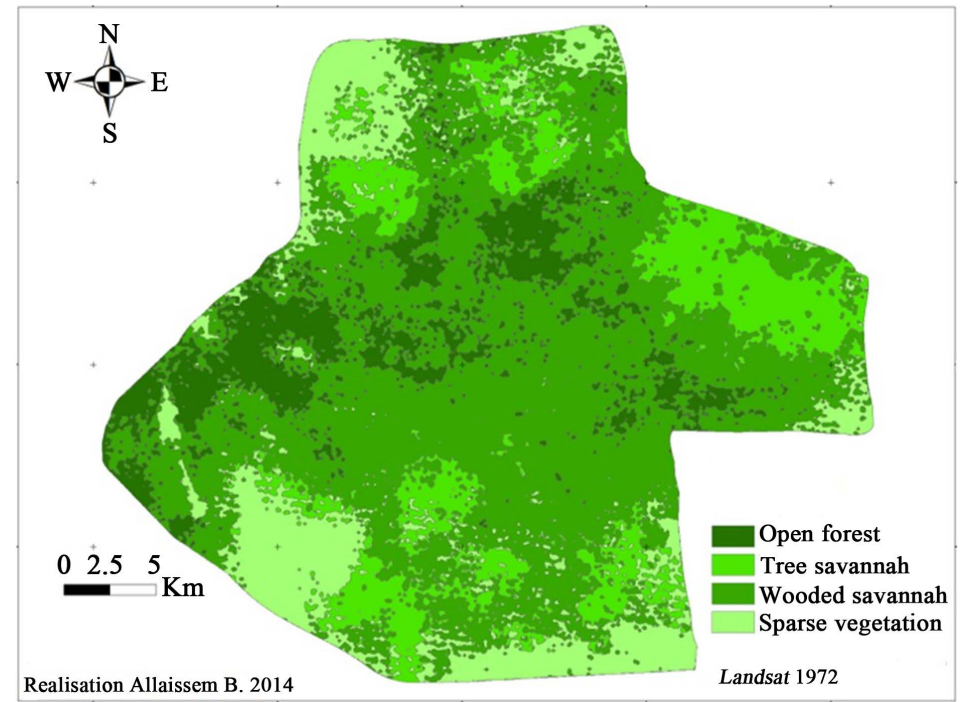

Figure 2. Land cover of classified forest of Djoli-Kera in 1972.

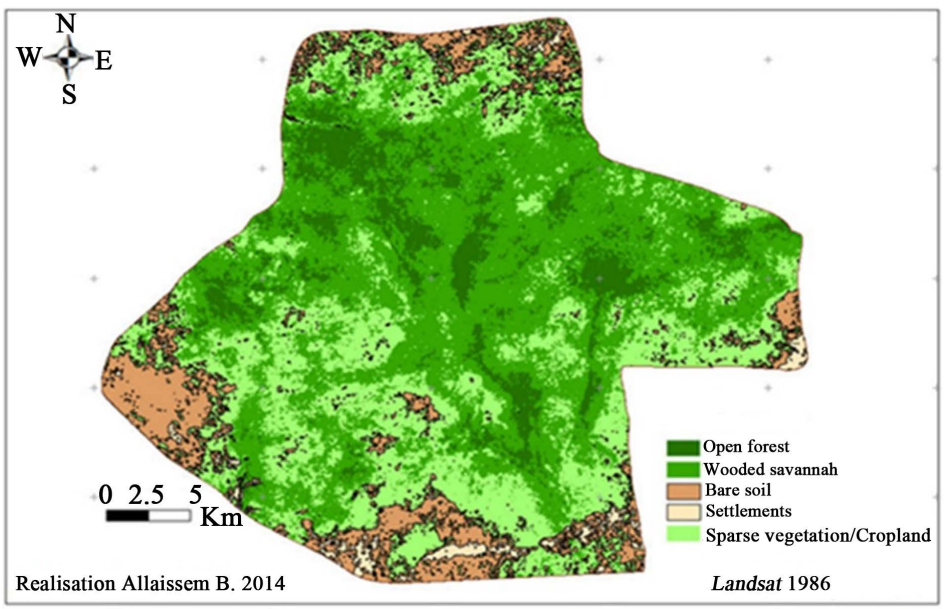

Figure 3. Land cover of classified forest of Djoli-Kera in 1986.

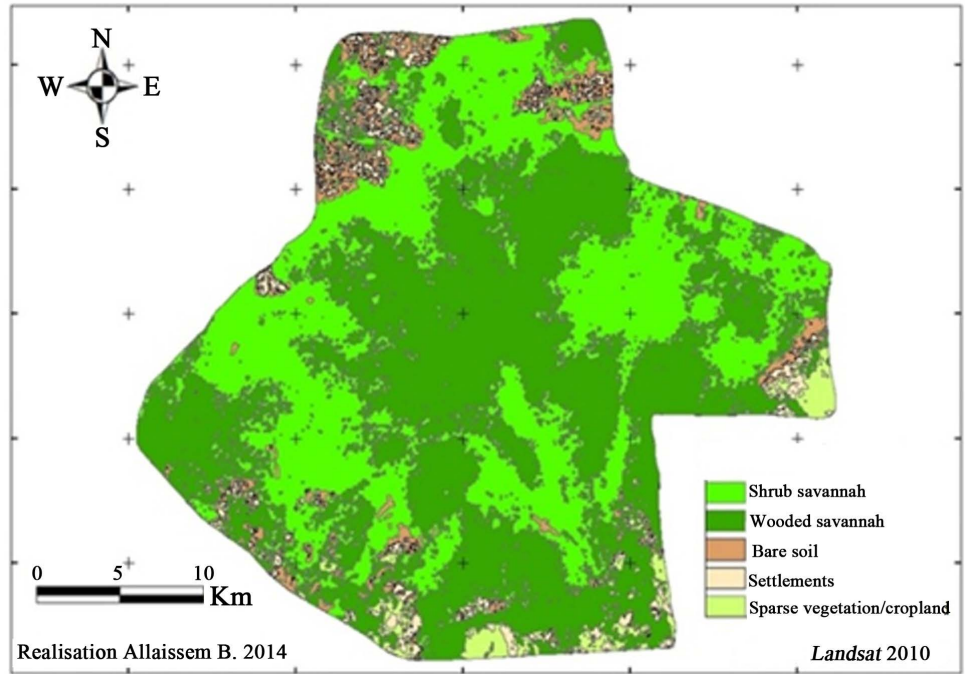

Figure 4. Land cover of classified forest of Djoli-Kera in 1999. 


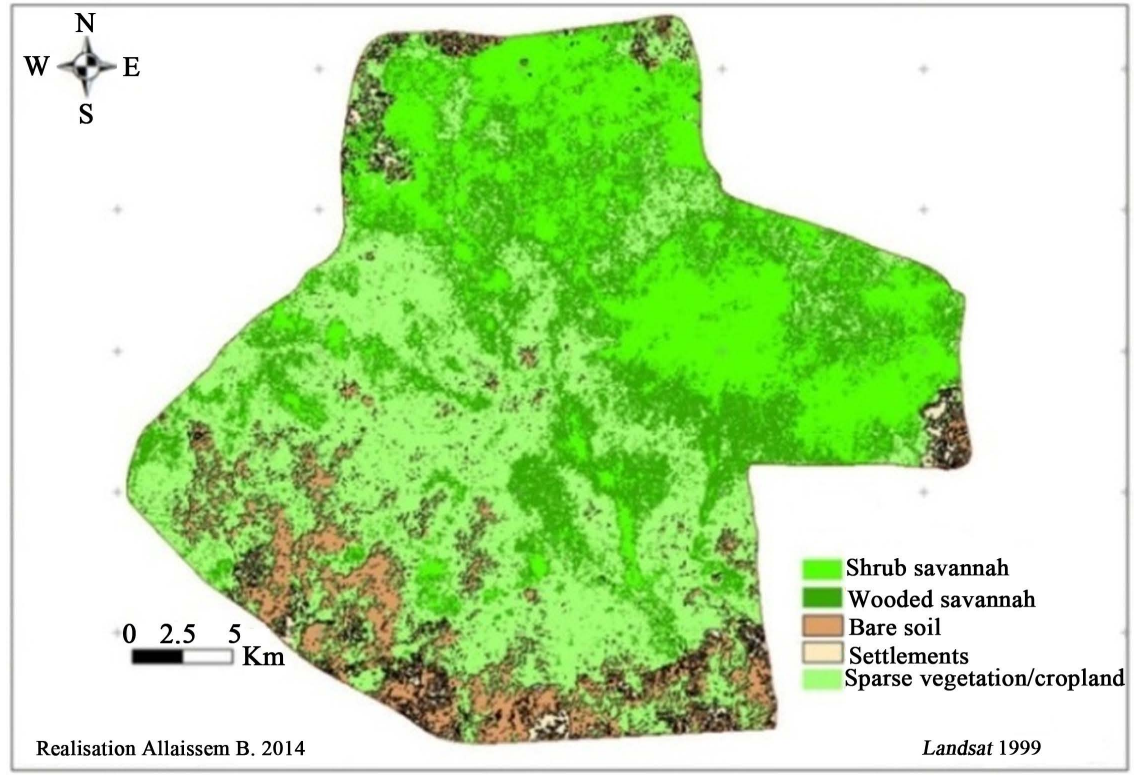

Figure 5. Land cover of classified forest of Djoli-Kera in 2010.

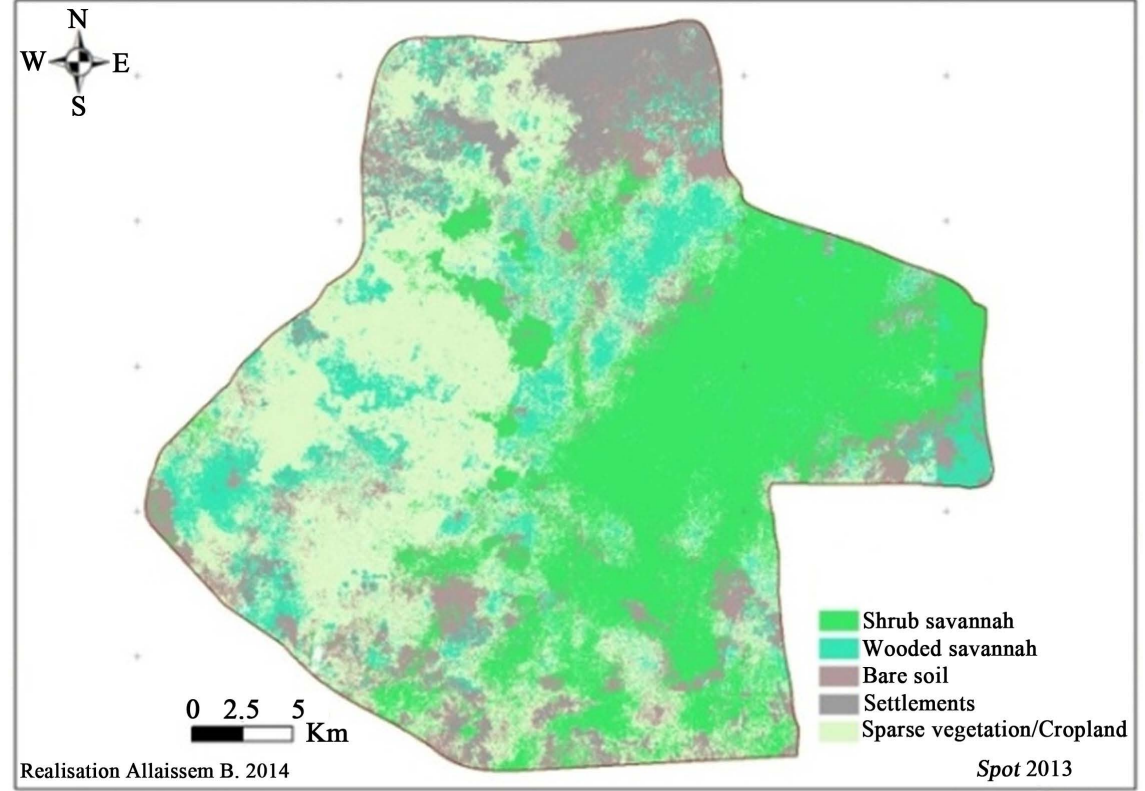

Figure 6. Land cover of classified forest of Djoli-Kera in 2013.

represented $21 \%$. Finally, the sparse vegetation that complements the physiognomy of the ecosystem was poorly represented with only $2 \%$ of the forest surface.

From 1986, a large change in the physiognomy of the forest occurred with remarkable ecological succession. The open forest decreased from $51 \%$ to $12 \%$, i.e. $39 \%$ of open forest surface converted into wooded savannah which surface area increased from $26 \%$ to $43 \%$. Sparse vegetation that almost did not exist gained space exponentially from $2 \%$ to $31 \%$ in just 14 years due to a total disappearance of the tree savannah (Figure 3 ). In addition, bare soils appeared occupying up to 
$12 \%$ of the classified forest.

In 1999 (Figure 4), the proportion of the wooded savannah began to decline, from $43 \%$ to $25 \%$; and there was also the appearance of the shrub savannah in a large proportion (22\%). So the open forest has completely disappeared. Fallows of very short duration (under 5 years) have spawned large areas of sparse vegetation which increased from $2 \%$ in 1972 to $31 \%$ in 1986 to reach $38 \%$ in 1999 . The proportions of bare soils and settlements did not change greatly between 1986 and 1999.

Between 1999 and 2010, the wooded savannah lost $11 \%$ of its surface, from 25 to $14 \%$, thus giving way to the shrub savannah, the settlements and the bare soils, which passed from $22 \%$ to $30 \%, 2 \%$ to $7 \%$ and $13 \%$ to $15 \%$ respectively (Figure 5).

In 2013, the shrub Savannah is the largest land cover and occupied $40 \%$ of the total area (Figure 6). The sparse vegetation with $28 \%$ of the total area lost $6 \%$ of its surface between 2010 and 2013, from 34\% to 28\%. For the wooded savannah, the variation between 2010 and 2013 was only $2 \%$ as a result of application of the measures taken in 2008 that prohibit wood extraction and agriculture within the classified forest. Table 1 shows the dynamic of different land cover surface areas from 1972 to 2013.

It appears from this table that the open forest that existed in 1972 disappeared completely to give way to shrub savannah and wooded savannah. The latter also lost its area until it remained only 12\% in 2013. Between 1972 and 1986, the proportion of wooded savannah decreased and that of the tree savannah and shrub savannah increased. The bare soils, which did not exist in 1972, appeared in 1986 and its surface area varied weakly during these years except in 2010 it reached about $15 \%$ of the surface area of the FCDK. Similarly, settlements area that were also non-existent appeared in the same year and maintain their growing pace until today.

Table 1. Dynamic of different land-cover surface areas from 1972 to 2013.

\begin{tabular}{ccccccccccc}
\hline \multirow{2}{*}{ Land-cover } & \multicolumn{2}{c}{1972} & \multicolumn{2}{c}{1986} & \multicolumn{2}{c}{1999} & & 2010 & \multicolumn{2}{c}{2013} \\
\cline { 2 - 9 } & Area (ha) & $\%$ & Area (ha) & $\%$ & Area (ha) & $\%$ & Area (ha) & $\%$ & Area (ha) & $\%$ \\
\hline Open Forest & 47,497 & 51 & 10,876 & 12 & 0 & 0 & 0 & 0 & 0 & 0 \\
Wooded Savannah & 23,932 & 26 & 40,739 & 43 & 23,312 & 25 & 12,762 & 14 & 11,831 & 12 \\
Tree Savannah & 20,054 & 21 & 0 & 0 & 0 & 0 & 0 & 0 & 0 & 0 \\
Shrub Savannah & 0 & 0 & 0 & 0 & 20,472 & 22 & 28,195 & 30 & 37,513 & 40 \\
Sparse Vegetation & 2245 & 2 & 28,916 & 31 & 35,390 & 38 & 32,308 & 34 & 25,943 & 28 \\
Settlements & 0 & 0 & 1943 & 2 & 2569 & 2 & 6381 & 7 & 7383 & 8 \\
Bare soil & 0 & 0 & 11,254 & 12 & 11,985 & 13 & 14,082 & 15 & 11,058 & 12 \\
Total & 93,728 & 100 & 93,728 & 100 & 93,728 & 100 & 93,728 & 100 & 93,728 & 100 \\
\hline
\end{tabular}




\subsection{Agents and Causes of Land Cover Change}

\subsubsection{Native Population}

Eighty (51.95\%) of the 154 respondents are native of the surveyed villages. They make up the population of large cantons that existed more than a century ago. In the canton of Djoli, big villages like Hasan and Gayam are closest to the classified forest with several settlements installed inside the classified forest. These villages grow and exploit farmland only on the southern and western sides due to the presence of Manda National Park in the north and east. They are therefore trapped between two protected areas and forced to abuse the rights of use granted to them. In fact, the classification decree of this forest granted to the inhabitants of the village Gayam the authorization to clear and cultivate within the classified forest on a strip of land of one kilometer length following the road. With demographic growth, the allocated space became very insufficient to contain the population flow. In all the cantons surveyed, populations carry out activities within the classified forest. Even the inhabitants of the villages Kera, Benguéwé and Dokassi, which are at least 7 kilometers away from the classified Forest.

\subsubsection{Non-Native Population}

Of the 154 persons surveyed, 74 (i.e. 48.05\%) are non-native, coming from others villages or region of Chad. Their settlement dates from an average of $21.2 \pm$ 14.5 years. All the 4 cantons around the classified forest are concerned. This population is either transhuman pastoralists who come from various horizons looking for pasture (6.76\%), or farmers looking for fertile land (21.26\%) or living space $(60 \%)$. The abundance of villages in the canton of Djoli in the classified forest is justified by the flow of the populations, sent away from the Manda National Park in 1967.e classified forest, practice agriculture there.

\subsubsection{Perceptions of Vegetation Degradation by Local Community}

The existence of the classified forest was made public only from 2007 due to an intensive awareness-raising operation carried out by the conservation and sustainable use of biodiversity project in the medium-Chari and the establishment of the local management committees. Survey results revealed that $89.61 \%$ of respondents are aware of the existence of the classified forest. However, of the entire population that is aware, $73.91 \%$ said that they heard about it less than 5 years ago, $26.09 \%$ heard about it more than 10 years ago. Respondents who know about the existence of classified forest for more than 10 years are mostly the older generation who attended or participated in its delimitation a few years after the classification. We also notice that population ignores the classified forest boundaries. Indeed, of the 138 respondents knowing the existence of this forest, $46.40 \%$ ignore the boundaries and $53.60 \%$ know them among which only $25.36 \%$ respect them. There is encroachment into the classified forest by local population who practice various activities within the forest. They perceive the degradation of the vegetation cover and the causes are given in Figure 7. Many 


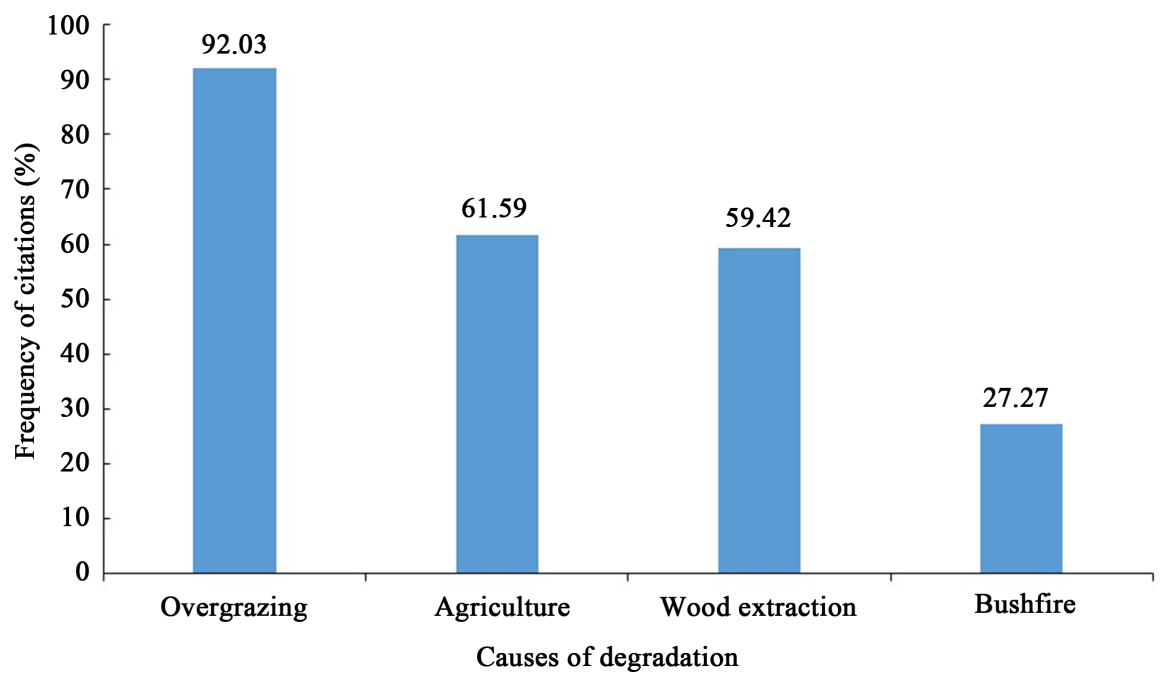

Figure 7. Frequency of citation of various causes of vegetation degradation by the local community.

persons mentioned more than one cause. Activities which contribute to such degradation include, livestock, agriculture, wood extraction and bushfire.

\subsubsection{Overgrazing/Livestock}

In the opinion of most of those surveyed other than transhuman pastoralists or settled breeders, livestock is the most devastating activity within the classified forest. Although $92 \%$ of respondents confirmed the straying of animals in the FCKD, only $15 \%$ said they had grazed their animals in the classified forest. For the most part, the herds belong to the livestock breeders who are in a process of settlement and this is confirmed by the presence of numerous "ferricks" build in and around the classified forest. Grazing affects vegetation in the classified forest in two ways: firstly by the building of permanent or temporary ferricks (in rainy season) near the ponds; and secondly by the early migration of transhuman pastoralists who destroy almost everything in their passage. Straying of animals directly affects woody resources. Woody pruning is increasing in the classified forest when herbaceous biomass is depleted towards the end of the dry season. Because of pruning some species are threatened by extension in the FCDK. These include Strychnos sp., Daniela oliveri, Vitellaria paradoxa, Khaya senegalensis, Parkia biglobosa, Amblygonocarpus andongensis. The disappearance of several herbaceous species (Schizachyrium sanguineum, Andropogon sp., Cymbopogon giganteus, Hyparrhenia bagirmica, Hyperthelia dissolute) is also attributed to overgrazing.

\subsubsection{Agriculture}

The FCDK has lost a large part of its surface area to agriculture, which is unfortunately slash and burn. Agriculture occupies about $28 \%$ of the total area of the FCDK and it practiced by $23.8 \%$ of respondents. Surface areas cultivated by farmers vary from five to more than twenty hectares. The main crops are: cassava (Manihot esculenta), millet (Pennisetum glaucum), maize (Zea mays), sesame 
(Sesamum indicum), okra (Hibiscus escalentus), sorrel (Hibiscus sabdaripha), bean (Phaseolus vulgaris) and peanuts (Arachis hypogaea) for food crops and cotton (Gossypium barbadens) for cash crops. Farmers do not plant trees because they don't own this land. However, during the clearing of farms, some useful species are preserved, including: Faidherbia albida, Zizyphus mauritiana, Vitellaria paradoxa, Tamarindus indica, Parkia biglobosa, Detarium microcarpum and Pterocarpus lucens.

\subsubsection{Wood and Non-Timber Forest Products Extraction}

The extraction of firewood and timber is the third driver of degradation after grazing and agriculture. Villages surrounding the classified forest largely depend on firewood and charcoal as their main source of energy. 100\% of the respondents use firewood as a main source of energy and only $15 \%$ use both firewood and charcoal as domestic source of energy. However charcoal is mainly use for the cooking of bricks used for construction. Poles for construction are also harvested in the classified forest. Therefore harvesting of poles is not to be underestimated as the entire population (100\% of respondents) has at least one house with a straw roof, which shows that the frame was constructed with fresh wood. Sale of firewood, charcoal and poles generate additional income when agricultural yields are poor. The proximity of Sarh and Koumra cities provides the main market and encourages cutting of trees for firewood, charcoal and construction purposes.

Many non-timber forest products are also extracted from the forest, endangering and depleting many species. Indeed, all respondents agreed that they use non-timber forest products from the forest, mainly for traditional medicine and for food. Products collected are tubers, fruits, honey, straw, bamboo, roots, barks and leaves of trees. The availability of non-timber forest is reducing due to unsustainable collection techniques.

\subsubsection{Bush Fires}

A very devastating phenomenon, bushfires are cited as cause of degradation of FCDK by $27.27 \%$ of respondents who say that they are lit between the months of November and March (the peak between December and January), accusing livestock breeders for being responsible. In general, these pastoralists light fires to promote the growth of young shoots that are very well-grazed by animals.

\section{Discussion}

Concerning data collection, for the villages within the classified forest, the populations, having been advised of their eventual evicting of the forest, reserved us a rather cold reception during the interviews. Therefore, the answers were provided with rudeness and a lot of reserve. This could affect the results of this research.

The open forest which was the main land cover with $51 \%$ of the surface area of the classified forest in 1972 gave way to a shrub savannah and sparse vegetation 
consisting of croplands and fallows which in 2013 occupy respectively $40 \%$ and $28 \%$ of the total surface area. These results are similar to those found by Avakoudjo et al. (2014) and Benoudjita \& Djinet (2017) in and around the periphery of the Benin part of Regional Park of W. and Manda National Park in Chad respectively where the open forest disappeared over the years and different to that found by Maarouhi et al. (2011) in the Niger part of Regional Park of W., where the area of the open forest increased by $1.7 \%$ between 1984 and 2002. In the classified forest of Djoli-Kera, protection and control are very recent, and this situation has allowed surrounding population to practice various illegal activities that affected forest cover.

Deforestation and degradation of FCDK is clearly perceptible between 1972 and 1999. This brutal land cover change is a result of migration to the south of the country of civil servants who fled the civil war in years 1970 and converted into farmers and breeders. They largely depended on natural resources and an over exploitation led to a rapid land cover change. Between 1999 and 2010, degradation is moderate and almost stable between 2010 and 2013 . This may be explained by measures taken by the Chadian state in 2008 which prohibited activities within FCDK.

The main agents of land cover change are the native populations, which account for $51.95 \%$ of the population and non-natives $(48.05 \%)$. With the population growth and Manda National Park in the east, space and resources are becoming increasingly limited for the populations, which causes them to encroach into the classified forest. Populations perceive livestock, agriculture, wood extraction and bushfires as the main drivers of FCDK degradation. The reasons for the practice of activities inside this forest include the lack of land and resources outside the classified forest and ignorance of its boundaries. The FCDK resources are threatened by the proliferation of villages around the forest. Several ferricks are built inside the forest, a sign of the settlement of nomad breeders. The underlying causes of deforestation are population growth, and poor governance. Indeed from 1955 the year of classification until 2008, no effective protection measures were taken to conserve the resources of this forest. Similar drivers of degradation have also been observed by Saradoum (2012), Avakoudjo et al. (2014) and Benoudjita \& Djinet (2017) in Chad and in other West African countries. In Cameroon, Wafo et al. (2006) and Momo et al. (2018) have found same degradation trends and similar drivers respectively for the Madjam forest reserve in the far north and the Koupa-Matapit gallery forest in the West. In Tanzania, Makunga \& Misana (2017) identified agriculture, wood extraction and expansion of settlement area as main drivers of degradation of Masito-Ugalla ecosystem.

In Djoli-Kera classified forest, overgrazing and unsustainable extraction of wood and non-timber forest products collection threaten the extinction of certain plant species. Aerial grazing which consist of pruning trees to feed animals is a widespread practice. All breeders use this harmful method to feed their herds, especially during drying seasons. The negative impact of overgrazing on 
vegetation cover has been described by Hountondji (2008) in Benin. For the extraction of non-timber products, Lescuyer (2010) made similar observations in his study on the economic importance of non-timber forest products in some villages in southern Cameroon, pointing out that farmers destroy some plants in order to make their path to the raffia plant.

Man has a great impact on the land cover through the activities he leads. This situation is not specific only to Chad. In tropical countries as reported by several authors, the main drivers of degradation and deforestation are the combination of several factors, including the expansion of peasant farming and the extraction of wood (Geist \& Lambin, 2002; Defourny et al., 2011). However, in Chad, unlike most countries of Congo basin, breeding is more intensely practiced. It represents an activity that affects a significant proportion of the population (40\%), and its contribution to the gross domestic product aside from oil is estimated at $17 \%$ (Koussou, 2008).

For Geist and Lambin (2002) factors that enhance deforestation and forest degradation fall into three categories namely: proximate causes, underlying causes and other factors. Proximate factors include agricultural expansion, wood extraction, and infrastructure extension while the underlying causes are demographic, economic, technological, policy and institutional as well as cultural or socio-political factors. Other factors include land characteristics like soil quality; biophysical factors such as soil fertility and social trigger event such as wars. A combination of many of these factors has led to the land cover change in Djoli-Kera classified forest. In addition to human pressures, we must underline the climatic conditions that has accentuated the ecological succession of the vegetation. Indeed these region faced several dry periods and shortage of rainfall (1974, 1984 , 1998) which are associated to the regression of open forest and tree savannah and an expansion of shrub savannah (Ouya, 2010).

The results of this study not only address the lack of information on forest cover changes and drivers, but provide a basis for conservation planning of this classified forest. Awareness-raising, monitoring and regulation of access to resources must be pursued, and the local populations must be assisted in the planting of trees and the setting up of more efficient farming and breeding systems to reduce pressure on the forest's resources.

\section{Conclusion}

In Djoli-Kera classified forest, land cover change has resulted over the years to several ecological successions affecting the physiognomy of the classified forest (disappearance of the open forest, appearance of shrub savannahs and sparse vegetation). The main drivers of these changes are agriculture, livestock, wood extraction, settlements, bushfire and population increase. Deforestation was very intense between 1972 and 1999 and almost stable between 2010 and 2013 as a result of measures taken in 2008 for the management and conservation of this classified forest. It is therefore essential to continue to raise awareness, monitoring 
and regulation of access to the resources. In addition, managers of this forest must accompany local populations in the planting of trees, the establishment of agricultural and higher-performing farming and breeding systems in order to reduce the pressure on the forest's resources.

\section{References}

Avakoudjo, J., Mama, A., Toko, I., Kindomihou, V., \& Sinsin, B. (2014). Dynamique de l'occupation du sol dans le Parc National du W et sa périphérie au nord-ouest du Bénin. International Journal of Biological and Chemical Sciences, 8, 2608-2625.

Benoudjita, N., \& Djinet, I. A. (2017). Comment les aires protégées structurent les écosystèmes des périphéries. International Journal of Biological and Chemical Sciences, $11,2225-2242$.

Boulanodji, E., \& Saradoum, G. (2013). Plan d'aménagement de la forêt classée de Djoli-Kera 2014-2024, version provisoire. Ministère de l'Environnement et des ressources naturelles, Tchad. $74 \mathrm{p}$.

Defourny, P., Delhage, C., \& Kibambelubamba, J. P. (2011). Analyse quantitative des causes de la déforestation et de la dégradation des forêts en République Démocratique du Congo. Kinshasa: UCL/FAO/CN REDD.

Dossou, M. E., Houessou, G. L., Lougbégnon, O. T., Tenté, A. H. B., \& Codjia, J. T. C. (2012). Étude ethnobotanique des ressources forestières ligneuses de la forêt marécageuse d'Agonvé et terroirs connexes au Bénin. Tropicultura, 3, 41-48.

FAO (2010). Global forest Resources Assessment 2010-Main Report. Forestry Paper. No. 163, Rome: FAO.

FAO (2016). State of the World Forests. Rome: FAO. http://www.fao.org/publications/sofo/2016/en/

Geist, H. J., \& Lambin, E. F. (2002). Proximate Causes and Underlying Driving Forces of Tropical Deforestation. BioScience, 52, 143-150. https://doi.org/10.1641/0006-3568(2002)052[0143:PCAUDF]2.0.CO;2

Grau, H. R., Aide, T. M., Zimmerman, J. K., Thomlinson, J. R., Helmer, E., \& Zou, X. (2003). The Ecological Consequences of Socioeconomic and Land use Changes in Postagriculture Puerto Rico. BioScience, 53, 1159-1168.

https://doi.org/10.1641/0006-3568(2003)053[1159:TECOSA]2.0.CO;2

Hansen, M. C., Potapov, P. V., Moore, R., Hancher, M., Turubanova, S. A., Tyukavina, A., \& Townshend, J. R. G. (2013). High-Resolution Global Maps of 21st-Century Forest Cover Change. Science, 342, 850-853. https://doi.org/10.1126/science.1244693

Hountondji, Y. C. (2008). Dynamique environnementale en zone sahélienne de l'Afrique de l'Ouest: Analyse des modifications et évaluation de la dégradation du couvert végétal (131 p).Thèse de doctorat, Liège: Université de Liège.

Koussou, M. O. (2008). Dynamique des changements dans le secteur de l'élevage au Tchad: Le cas de la filière laitière de N'Djamena (242 p). Thèse de Doctorat, Paris: Agro ParisTech.

Le Guen, J. M. (2010). Protection des forêts tropicales et de leur biodiversité contre la dégradation et la déforestation. République Française. 104 p. http://www.oeconomia.net/private/dvlptdurable/deforestation-oct2010.pdf

Lescuyer, G. (2010). Importance économique des produits forestiers non ligneux dans quelques villages du Sud-Cameroun. Bois et Forêts des Tropiques, 304, 15-24.

https://doi.org/10.19182/bft2010.304.a20442 
Loveland, T. R., \& Dwyer, J. L. (2012). Landsat: Building a Strong Future. Remote Sensing of Environment, 122, 22-29. https://doi.org/10.1016/j.rse.2011.09.022

Lucas, R., Blonda, P., Bunting, P., Jones, G., Inglada, J., Arias, M., \& Mairota, P. (2015). The Earth Observation Data for Habitat Monitoring (EODHaM) System. International Journal of Applied Earth Observation and Geoinformation, 37, 17-28. https://doi.org/10.1016/j.jag.2014.10.011

Maarouhi, M. M., Ali, M., Mbow, C., Saadou, M., \& Bachmann, Y. (2011). Dynamique Spatio-Temporelle des forêts claires dans le parc national du W du Niger. Sècheresse, 22, 108-116.

Makunga, J. E., \& Misana, S. B. (2017). The Extent and Drivers of Deforestation and Forest Degradation in Masito-Ugalla Ecosystem, Kigoma Region, Tanzania. Open Journal of Forestry, 7, 285-305. https://doi.org/10.4236/ojf.2017.72018

Momo, M. C. S., Njouonkouo, A. L., Temgoua, L. F., Zangmene, R. D., Taffo, J. B. W., \& Ntoukpa, M. (2018). Land Use/Land Cover Change and Anthropogenic Causes around Koupa-Matapit Gallery Forest, West-Cameroon. Journal of Geography and Geology, 10, 56-65. https://doi.org/10.5539/jgg.v10n2p56

Ouya, B. (2010). Conservation et utilisation durable de la biodiversité autour et dans les aires protégées du sud-est du Tchad: Cas du parc de manda et de la forêt de Djoli-Kera (296 p). Thèse de doctorat, Montpellier: Université de Montpellier.

Romijn, E., Lantica, C. B., Herold, M., Lindquist, E., Ochieng, R., Wijaya, A., \& Murdiyarso, D. (2015). Assessing Change in National Forest Monitoring Capacities of Tropical Countries. Forest Ecology and Management, 352, 109-123.

https://doi.org/10.1016/j.foreco.2015.06.003

Saradoum, G. (2010). Rapport de consultation collecte des données pour la mise en place des corridors de migration de la faune sauvage vers le parc national de manda: Données écologiques 2010 (45 p). Projet conservation et utilisation durable de la biodiversité dans le Moyen-Chari.

Saradoum, G. (2012). Étude phytosociologique et diagnostic faunique du parc national de Manda au Tchad. Eléments pour un aménagement (183 p). Thèse de doctorat, Dakar: Université Cheik AntaDiop de Dakar.

Wafo, T. G., TsayemDemaze, M., \& Fotsing, J. M. (2006). L'information spatialisée comme support d'aide à la gestion des aires protégées au Cameroun: Application à la réserve forestière de Laf-Madjam (9 p). Interactions Nature-Société, analyse et modèles, UNR6554 LETG, La Baule.

Yeshaneh, E., Wagner, W., Exner-Kittridge, M., Legesse, D., \& Blöschl, G. (2013). Identifying Land Use/Cover Dynamics in the Koga Catchment, Ethiopia, from Multi-Scale Data, and Implications for Environmental Change. ISPRS International Journal of Geo-Information, 2, 302-323. https://doi.org/10.3390/ijgi2020302 